\title{
Główne przyczyny akceptacji przemocy niepaństwowych ugrupowań zbrojnych we współczesnym Afganistanie
}

\begin{abstract}
Streszczenie: Celem artykułu jest analiza głównych przyczyn akceptacji przemocy niepaństwowych ugrupowań zbrojnych we współczesnym Afganistanie. Problem badawczy ujęty został w pytaniu, jakie są główne przyczyny akceptacji przez część społeczeństwa afgańskiego prowadzenia działań zbrojnych przez podmioty niepaństwowe? Chodzi głównie o radykalne grupy islamistyczne, watażków i ich nielegalne milicje, ale także o organizacje terrorystyczne i przestępcze. Wśród głównych przyczyn autor wskazuje ingerencję mocarstw, okupację i działania wojsk koalicyjnych; konflikt kulturowy i godzenie w wartości kulturowe; korupcję i niekompetencję władz; konflikty wewnętrzne oraz narkobiznes. Mają one charakter zarówno historyczny, polityczny, kulturowy, społeczny i ekonomiczny, a w ich tle znajdują się przesłanki natury psychologicznej. Ponadto są złożone i wzajemnie ze sobą powiązane. Spajają je wspólne elementy, takie jak odmienne postrzeganie tych samych zjawisk przez strony konfliktu, rozbieżny światopogląd i system wartości oraz kolizyjne lub sprzeczne cele i interesy. W ramach postkolonialnego nurtu podejścia do bezpieczeństwa szczególne znaczenie odgrywają historyczne i współczesne stosunki z mocarstwami. Przemoc zbrojna każdego roku pochłania w Afganistanie tysiące ofiar. Przyczyny tej przemocy, natura konfliktu i specyfika walczących stron powodują, że w najbliższym czasie nie należy się spodziewać zmniejszenia poziomu przemocy zbrojnej w Afganistanie. Społeczność międzynarodowa nie może odwrócić się od Afganistanu, ponieważ to doprowadziłoby do jeszcze poważniejszej destabilizacji kraju i w konsekwencji odzyskania władzy przez talibów.
\end{abstract}

Słowa kluczowe: współczesny Afganistan, niepaństwowe ugrupowania zbrojne, przemoc zbrojna, rząd Afganistanu

\section{Wprowadzenie}

$\mathbf{Z}$ amachy terrorystyczne z 11 września 2001 r. przeprowadzone przez Al-Kaidę na terytorium Stanów Zjednoczonych sprowokowały administrację George’a W. Busha do zbrojnej odpowiedzi na szeroką skalę. Operacja Trwała Wolność (Operation Enduring Freedom - OEF) w Afganistanie stanowiącym kolebkę międzynarodowego dżihadu przekształciła się w wieloletnią wojnę i próbę stabilizacji państwa przy wsparciu ze strony towarzyszącej jej misji Międzynarodowych Sił Wsparcia Bezpieczeństwa (International Security Assistance Force - ISAF). Szanse na pokój i bezpieczeństwo zostały zniweczone wraz z rozwojem w państwie rebelii. Według ostrożnych szacunków od 2001 roku przemoc zbrojna pochłonęła w Afganistanie ponad 120 tys. osób (Crawford, 2016, s. 1; UNAMA, 2018). Obecnie nie widać perspektyw na zakończenie konfliktu, w związku z czym liczba ta z roku na rok może się zwiększać.

Celem artykułu jest analiza głównych przyczyn akceptacji przemocy niepaństwowych ugrupowań zbrojnych we współczesnym Afganistanie. Problem badawczy ujęty został w pytaniu, jakie są główne przyczyny akceptacji przez część społeczeństwa afgań- 
skiego prowadzenia działań zbrojnych przez podmioty niepaństwowe? Dla uściślenia problemu badawczego zadano pytania szczegółowe, w tym jaki charakter mają te przyczyny oraz czy istnieje zależność między nimi? Główną tezą artykułu jest stwierdzenie, że do głównych przyczyn akceptacji przemocy niepaństwowych ugrupowań zbrojnych w Afganistanie należą ingerencja mocarstw, okupacja i działania wojsk koalicyjnych; konflikt kulturowy i godzenie w wartości kulturowe; korupcja i niekompetencja władz; konflikty wewnętrzne oraz narkobiznes. Przyczyny te mają charakter zarówno historyczny, polityczny, kulturowy, społeczny i ekonomiczny, a w ich tle znajdują się przesłanki natury psychologicznej. Stwierdzono również, że są one złożone i wzajemnie ze sobą powiązane.

Przemoc stanowi zamierzoną groźbę lub faktyczne użycie siły fizycznej lub władzy przeciwko jednostce lub zbiorowości, które stwarza prawdopodobieństwo lub powoduje uszkodzenie ciała, śmierć, krzywdę psychologiczną, dysfunkcje rozwojowe albo ograniczenie wolności (Koplan, Rosenberg, Krug, 1998, s. 3). Przemoc zbrojna dodatkowo wymaga zastosowania broni (Coupland, 2001, s. 33).

Niepaństwowe ugrupowania zbrojne (non-state armed groups) stanowią głównie organizacje rebelianckie, terrorystyczne, przestępcze i nielegalne milicje. W Afganistanie najbardziej aktywnym ugrupowaniem rebelianckim są talibowie, których struktura nie jest spójna wewnętrznie. W państwie tym coraz większą rolę odgrywa współpracująca z talibami sieć organizacyjna Dżalaluddina Hakkaniego. Z kolei przez lata aktywna militarnie Hizb-i Islami Gulbuddina Hekmatjara w 2016 roku zawarła z rządem Afganistanu porozumienie o zawieszeniu broni. W Afganistanie działa także szereg innych, mniejszych organizacji rebelianckich. Do destabilizacji państwa istotnie przyczyniają się dżihadystyczne organizacje terrorystyczne, w tym rywalizujące o wpływy Al-Kaida i Daesh. Według Global Terrorism Index 2019 w roku poprzedzającym publikację Afganistan był państwem najbardziej dotkniętym zjawiskiem terroryzmu na świecie (Institute for Economics \& Peace, 2019, s. 2). W Afganistanie działają również nielegalne milicje poszczególnych watażków oraz znaczna liczba grup przestępczych. W dyskursie politologicznym niepaństwowe ugrupowania zbrojne charakteryzowane są jako zagrażające społeczeństwu i państwu. Niektóre z tych podmiotów generują także zagrożenia w wymiarze międzynarodowym (Englehart, 2016, s. 171).

Stosujące przemoc zbrojną ugrupowania niepaństwowe współcześnie wychodzą poza działania z zakresu tradycyjnego wyrządzania krzywdy. W zależności czy są to grupy bardziej o charakterze rebelianckim, ekstremistycznym, czy przestępczym, w różnym stopniu próbują wprowadzać nieformalne i nieliberalne formy rządzenia. Mimo, że zazwyczaj nie zapewniają one społeczeństwu podstawowych usług i generalnie nie reprezentują jego interesów, to zabiegają o tworzenie specyficznej więzi z obywatelami. Budowana jest ona wokół wspólnych celów politycznych, jak na przykład w przypadku Afganistanu obalenia władz współpracujących z Zachodem i usunięcia z kraju obcych wojsk. Z drugiej jednak strony mogą to być zachęty stricte materialne. Niezależnie od powodów, przyzwolenie społeczne znacząco ułatwia im prowadzenie walki z oficjalnymi instytucjami państwowymi i państwowymi siłami bezpieczeństwa (Briscoe, 2013, s. 1-2).

Stosowanie przemocy przez niepaństwowe ugrupowania zbrojne ułatwione jest w państwach upadłych (failed states), w których brakuje efektywnej kontroli rządowej i występuje niezdolność sprawowania podstawowych funkcji państwowych. Sprzyja to 
zachwianiu ładu i porządku społecznego, wzrostowi przestępczości, eskalacji wewnętrznej przemocy, w tym wybuchowi konfliktów zbrojnych. To z kolei dalej pogłębia słabość państwa i jego struktur (Geib, 2009, s. 128). Według Fragile State Index 2019, wskazującego kruchość/niestabilność państw, Afganistan zakwalifikowany został do grupy państw wysokiego zaalarmowania i sklasyfikowano go jako dziewiąte najbardziej niestabilne państwo na świecie (The Fund for Peace, 2019, s. 7).

Badania teoretyczne i empiryczne dotyczące niepaństwowych ugrupowań zbrojnych, wewnętrznych konfliktów zbrojnych i państw upadłych są zaawansowane. Zjawiska te pojawiają się głównie w państwach tzw. Trzeciego Świata. Można je interpretować między innymi w ramach postkolonialnego nurtu podejścia do bezpieczeństwa. Prezentowane przez Mohammeda Ayooba podejście do bezpieczeństwa państw Trzeciego Świata określane jest mianem „realizmu podrzędnych” (,subaltern”). Na skutek uwarunkowań historycznych i kolonialnej eksploatacji państwa te zajmują niskie szczeble w hierarchii międzynarodowej. Warunkiem poprawy tej sytuacji jest wzmocnienie instytucji państwowych i poprawa jakości rządzenia (Czaputowicz, 2012, s. 212-213), co najczęściej wymaga wsparcia ze strony mocarstw. Działania te często podsycają jednak konflikty, które mają elementy imperialnego dziedzictwa, włącznie z bezpośrednimi interwencjami zbrojnymi jednego lub większej liczby mocarstw (Ayoob, 1980, s. 239-244). Zjawiska te zwróciły szczególne zainteresowanie badaczy z zakresu nauk o polityce na początku lat 90. XX wieku wraz $\mathrm{z}$ wybuchem szeregu wojen domowych, w tym w Rwandzie (McQuinn, Oliva, 2018, s. 9-10). Badania pogłębiane były w okresie prowadzenia globalnej wojny z międzynarodowym terroryzmem, między innymi za sprawą interwencji zbrojnych w Afganistanie, Iraku i Syrii.

\section{Ingerencja mocarstw, okupacja i działania wojsk koalicyjnych}

Liczne wojny, najazdy i podboje prowadzone na przestrzeni wieków na obszarze współczesnego Afganistanu odcisnęły piętno w psychice ludności zamieszkującej te tereny. Poszczególne generacje przekazywały z pokolenia na pokolenie elementy swoistej kultury wojny (Jureńczyk, 2013, s. 23). Ziemie dzisiejszego Afganistanu znajdowały się między innymi pod panowaniem lub okupacją Ariów, Persów, Greków, Mongołów, Brytyjczyków i Rosjan, a w XXI wieku także Amerykanów. Nacje te próbowały narzucać lokalnej ludności własne rozwiązania systemowe, kulturę i obyczaje, a czasem nawet wierzenia. Za każdym razem prowadziło to do ksenofobii, wrogości i przemocy zbrojnej, a panowanie nigdy nie było trwałe. Współcześnie jednym z podłoży radykalnego islamizmu i bazującego na nim tzw. terroryzmu islamskiego jest przeświadczenie, że mocarstwa dążą do podboju świata islamu i zniszczenia jego wartości. Tak zwana „kultura upokorzenia”, będąca konsekwencją polityki mocarstw wobec państw muzułmańskich, powoduje, że część wyznawców Allaha, w tym Afgańczyków, przejawia skłonność do przemocy zbrojnej, w tym przemocy terrorystycznej (Moïsi, 2012, s. 126-127). Zazwyczaj przyświecają im wzniosłe idee obrony wiary, przekonań, ziemi i rodziny. Drapieżna polityka mocarstw eksponowana była zarówno w ideologii i propagandzie Al-Kaidy, jak i w doktrynie szkół koranicznych w Pakistanie, w których pobierało nauki gros talibów i rzesze Pasztunów, którzy oficjalnie nie wstąpili do ruchu (Jahangir, Javaid, 2018, s. 419). 
Współczesny Afganistan jest obszarem rywalizacji między potęgami państwowymi o globalnych interesach, w tym Stanami Zjednoczonymi, Chinami i Rosją, jak również mocarstwami regionalnymi, w tym przede wszystkim Pakistanem, Iranem i Arabią Saudyjską oraz aspirującymi do mocarstwowości ponadregionalnej Indiami. Każde z tych państw ma w Afganistanie swoje interesy polityczne, ekonomiczne i ideologiczne. Sympatyzują one z poszczególnymi ugrupowaniami politycznymi, watażkami i innymi podmiotami działającymi na jego terytorium. Próbują uczestniczyć w formułowaniu ich celów i dostarczają im wsparcia różnego typu, co podsyca wewnętrzny konflikt w Afganistanie. Obok Stanów Zjednoczonych największy wpływ na sytuację w tym państwie ma sąsiedni Pakistan. Wojska koalicyjne oraz Afgańskie Państwowe Siły Obrony i Bezpieczeństwa (Afghan National Defense and Security Forces - ANDSF) nie były i nadal nie są w stanie skutecznie izolować Afganistanu od Pakistanu, który stanowi dla rebeliantów i terrorystów relatywnie bezpieczną przystań oraz zaplecze logistyczne i rekrutacyjne (Sepp, 2006, s. 11). Przenikalność granicy z Pakistanem powoduje, że do działających w Afganistanie rebeliantów i terrorystów trafiają nowi rekruci, sprzęt wojskowy i środki finansowe. Współpraca z ekstremistami z sąsiednich państw następuje również przez granicę z Iranem, republikami środkowoazjatyckimi i Chinami.

Prawie zawsze wojskowe siły okupacyjne są niemile widziane przez społeczeństwa, na których terytorium stacjonują. Z tego względu możliwość ich pozytywnego wpływu na miejscową ludność jest ograniczona. Zazwyczaj mogą one jedynie stawiać żądania, które mają być zrealizowane pod groźbą użycia siły. Trudno jednak oczekiwać, że pojawi się pozytywne emocjonalne podejście danej społeczności do realizacji tych żądań (Lawless, Constantineau, 2017, s. 66-67). Próba przekonania o istnieniu wspólnego celu i wieloaspektowe wsparcie lokalnych społeczności miały zapewnić minimum akceptacji dla stacjonowania wojsk koalicyjnych. W praktyce na większości obszarów Afganistanu polityka ta nie przyniosła oczekiwanego skutku. Wręcz przeciwnie, wraz z przedłużającą się okupacją Afganistanu przez siły koalicyjne, przy braku wymiernych sukcesów w stabilizowaniu sytuacji bezpieczeństwa, pogłębiało się zmęczenie i niechęć społeczeństwa.

W XXI wieku skalę przemocy ze strony Afgańczyków zwiększała specyfika korzystania z siły militarnej przez wojska koalicyjne. Na relatywnie szeroką skalę stosowały one bowiem różne taktyki działań powietrznych, co miało stanowić wsparcie dla jednostek naziemnych, w tym ANDSF. Wraz ze znacznym ograniczeniem kontyngentów lądowych wzrosła intensywność nalotów. Coraz więcej z nich realizowana jest z wykorzystaniem systemów bezzałogowych. Poszczególne techniki ataków z powietrza mają różną precyzję rażenia, jednak zasadniczo powodują one większe straty wśród ludności cywilnej, niż użycie broni ręcznej w bezpośrednich starciach z wrogiem. To samo tyczy się również stosowanych w Afganistanie naziemnych systemów artyleryjskich różnego typu. Trudno bowiem z dużej odległości odróżnić bojownika od cywila, który może być podobnie ubrany. Nic nie pogłębia nienawiści wobec obcych tak bardzo, jak zabicie przez nich kogoś bliskiego, szczególnie członka rodziny. W Afganistanie samoistnie nakręca się spirala przemocy, ponieważ krewni i przyjaciele niezamierzonych ofiar szukają zemsty na sprawcach (Hoehn, Harting, 2010, s. 54-55).

Dowództwa OEF, ISAF i narodowych kontyngentów wojskowych stacjonujących w Afganistanie przykładały dużą uwagę do przestrzegania przez żołnierzy prawa, w tym zasad użycia siły (Rules of engagement - ROE) oraz poszanowania lokalnej kultury. 
Mimo to zdarzały się przypadki niesubordynacji oraz przejawy ograniczonej wiedzy i kompetencji międzykulturowych. Godzenie w zwyczaje i obyczaje ludności stacjonowanie wojsk jest szczególnie wrażliwą przestrzenią, która znacznie pogłębia niechęć wobec zagranicznych kontyngentów zbrojnych (Williams, 2011, s. 131). Frustrację wśród Afgańczyków wywoływało między innymi „ordynarne” przeszukiwanie domów w pogoni za bojownikami Al-Kaidy i talibami. Sporadycznie zdarzały się również bardziej jaskrawe przykłady niepożądanych działań, polegające na przykład na profanacji świętych pism islamu, czy bezczeszczeniu zwłok poległych bojowników. Każde z tego typu niewłaściwych zachowań zręcznie wykorzystywane było przez propagandę talibów, co pogłębiało ksenofobiczne nastroje wśród znacznej części Afgańczyków, a niektórych popychało do fizycznego oporu.

Niejednokrotnie do tragedii prowadziło nieodpowiednie reagowanie żołnierzy koalicyjnych na nieszablonowe zachowania cywilów, takie jak na przykład nacisk tłumu na żołnierzy, obrzucenie kamieniami pojazdów wojskowych, czy wbieganie na drogę przed kolumnę tych pojazdów (Ogdowski, 2011, s. 36-39). Najczęściej nieumiejętność żołnierzy wojsk koalicyjnych w radzeniu sobie z lokalnymi społecznościami wynikała z niewystarczającego wyszkolenia lub trudności w opanowaniu stresu. Rzadziej była to konsekwencja narastającej wrogości wobec Afgańczyków, czy po prostu bezmyślności i chuligaństwa.

Talibowie $\mathrm{i}$ inne ugrupowania rebelianckie stosują przemoc zbrojną przeciwko stacjonującym wojskom zagranicznym z wykorzystaniem dostępnych im taktyk militarnych. W wojnie o charakterze asymetrycznym naturalnym jest stosowanie metod partyzanckich i terrorystycznych. Są one tanie i efektywne, pozwalają zadawać znaczne straty silniejszemu wrogowi i jednocześnie zastraszać społeczeństwo, aby nie kolaborowało z okupantem. Ciągłe zagrożenie dla żołnierzy sił koalicyjnych, którego źródłem są także osoby identyfikowane jako cywile, negatywnie rzutuje na ich podejście do Afgańczyków. Aroganckie potraktowanie przez żołnierzy wzmaga z kolei niechęć mieszkańców, którzy go doświadczyli.

\section{Konflikt kulturowy i godzenie w wartości kulturowe}

Według Garretta J. Lawlessa, Philippe'a Constantineau i Alego Dizboni kultura nie może być rozprzestrzeniana przy użyciu siły zbrojnej, ponieważ nie doprowadzi to do osiągnięcia zamierzonego celu, a nawet pogorszy istniejący stan. Misją zachodnich kontynentów wojskowych stacjonujących w państwach upadłych powinno być wprowadzanie i utrzymanie bezpieczeństwa, a nie narzucanie zewnętrznych rozwiązań kulturowych. Nie oznacza to jednak, że siła militarna nie może być zastosowana przeciwko rozwiązaniom, które są nie do zaakceptowania przez społeczność międzynarodową. Działania takie są dopuszczalne, szczególnie w celu powstrzymania osób wyrządzających krzywdę niewinnym. Użycie przemocy zbrojnej przez społeczność międzynarodową jest szczególnie zasadne i pożądane w celu zahamowania motywowanego kulturowo ludobójstwa. Nie jest jednak zasadnym jej stosowanie w celu narzucenia społeczeństwu odpowiedniej formy rządów (Lawless, Constantineau, 2017, s. v). W Afganistanie były jednak przejawy „pacyfikowania” orężem i „demokratyzowania” za pośrednictwem ule- 
głych lokalnych elit (Gwiazda, 2007, s. 70). Zaszczepianie przez Zachód demokracji w znacznie różniących się kulturowo społeczeństwach muzułmańskich odbierane jest przez nie jako przejaw ingerencji w sprawy wewnętrzne, narzucania własnej woli i protekcjonalnego traktowania (Zając, 2010, s. 145).

Wprowadzanie do życia politycznego i społecznego zmian, które nie mają umocowania w rodzimej tradycji i są niezrozumiałe dla ludności, niechybnie prowadzi do oporu, a nawet agresji (Kamiński, 2008, s. 158). Szybkie i odgórne narzucenie demokracji charakterystycznym dla Azji Centralnej klanowym strukturom społecznym musiało spotkać się z brakiem akceptacji (Rączkiewicz, 2011, s. 214). Powołany przy wsparciu Stanów Zjednoczonych centralny rząd Afganistanu zraził konserwatywne środowiska lokalne uległością wobec Amerykanów i szybką modernizacją państwa na wzór zachodni (Sierakowska-Dyndo, 2007, s. 174-175). W Afganistanie nastąpiło zderzenie dwóch sprzecznych prądów ideowych, tj. fundamentalizmu z modernizmem. Islamiści odrzucają możliwość syntezy tradycyjnych wartości muzułmańskich z nowoczesnymi osiągnięciami ludzkości. Sprzeciwiają się oni, również przy użyciu siły zbrojnej, uniwersalizacji zachodniej kultury i systemu wartości (Jureńczyk, 2007, s. 77). Uważają bowiem, że te wprowadzają relatywizm moralny, a tym samym grzech i zepsucie, tak więc postrzegają je za wrogie (Modrzejewska-Leśniewska, 2010, s. 408-409). Ponadto w Afganistanie doszło do zderzenia charakterystycznej dla jego społeczeństwa kultury kolektywistycznej z indywidualistyczną kulturą Zachodu. O ile indywidualizm podkreśla znaczenie osobistej wolności i osiągnięć, o tyle kolektywizm skupia się na podporządkowaniu jednostki grupie (Gorodnichenko, Roland, 2012, s. 2).

Według prekursora teorii konfliktu kultur Johana T. Sellina zderzenie konkurencyjnych wobec siebie systemów aksjonormatywnych wywołuje u jednostki dysonans, dyskomfort psychiczny, a nawet zachowania dewiacyjne (Sellin, 1938, s. 97-103). Ludzie często nie potrafią odnaleźć się w nowej, obcej rzeczywistości, a jednocześnie tracą komfort i bezpieczeństwo psychiczne, jakie dawały im tradycyjne więzi, zwyczaje i obyczaje. Takie poczucie alienacji może wywoływać zdecydowany opór, w tym popychać do walki zbrojnej w obronie poprzedniego porządku. Prowadzonej przez afgańskich radykałów walce orężnej towarzyszą zintensyfikowane działania o charakterze propagandowym. Talibowie próbują utwierdzić w społeczeństwie przekonanie, że Amerykanie i ich sojusznicy walczą z islamem i kulturą afgańską. Aby treści te były lepiej przyjmowane przez Afgańczyków, próbują pogłębić w społeczeństwie ksenofobiczne nastroje i nienawiść do obcych. Czynią to na przykład oskarżając żołnierzy wojsk koalicyjnych o zabijanie cywilów, palenie ich domów, gwałcenie afgańskich kobiet i poniżanie mężczyzn (Langenfeld, 2011, s. 45).

Kontrowersje budzi również próba szybkiego narzucenia przez Zachód Afgańczykom szerokiego katalogu praw człowieka. Społeczeństwom zachodnim przyjęcie rozwiązań opartych na równości wszystkich jednostek z pierwszoplanową zasadą niedyskryminacji zajęło wieki. Zważywszy na niski poziom rozwoju cywilizacyjnego społeczeństwo afgańskie możemy zakwalifikować do kategorii przednowoczesnych. Dominuje w nim trybalizm, podzielone jest ono na warstwy społeczne, masy żyją na poziomie egzystencjalnym, miliony ludzi są niepiśmienne i mają ograniczony dostęp do nowoczesnych technologii komunikacyjnych. Mimo, że Afgańczycy niewiele mają wspólnego ze społeczeństwami ponowoczesnymi, to Zachód oczekuje, że powinni zrozumieć i zgodzić się na nadanie 
równych praw wszystkim grupom społecznym (Lawless, Constantineau, 2017, s. 66). Problem przede wszystkim dotyczy ważkiej w Afganistanie kwestii praw kobiet. W konserwatywnym społeczeństwie afgańskim różne są tradycyjne role kobiety i mężczyzny. Działania na rzecz ochrony kobiet przed przemocą i prześladowaniem są w pełni uzasadnione. Odgórne zrównanie praw politycznych, gospodarczych i społecznych kobiet i mężczyzn, bez uprzedniego, rozłożonego w czasie procesu edukacyjnego, budzi jednak zastrzeżenie. Emancypacja kobiet jest ważna i potrzebna oraz powinna stanowić jeden z zasadniczych celów. Nie może jednak mieć charakteru radykalnej zmiany prawnej. Zamiast tego powinna stanowić proces polegający na ewolucyjnych zmianach świadomościowych. Tylko stopniowo następujące przewartościowania społeczne w tym zakresie mogą zagwarantować kobietom, że nadane im prawa nie będą ustawową fikcją. Podejście takie ograniczyłoby również ryzyko ataków tradycjonalistów na postępowe kobiety.

Szybkie i radykalne próby narzucenia Afgańczykom zmiany sposobu życia praktycznie zawsze kończyły się oporem społecznym. Niezależnie czy miały one charakter wewnętrzny, jak na przykład reformy modernizacyjne postępowego króla Amanullaha Chana w latach 20. XX wieku, czy zewnętrzny, jak wprowadzanie przez Związek Radziecki rozwiązań socjalistycznych na przełomie lat 70 i 80 . XX wieku, skutecznie zwalczane były przez konserwatywnych Afgańczyków. Również w XXI wieku silne grupy afgańskich tradycjonalistów i fundamentalistów próbują położyć kres rozwiązaniom implementowanym z Zachodu.

\section{Korupcja i niekompetencja wladz}

Afganistan ma nikłe tradycje etatystyczne, a tym bardziej istnienia silnego rządu centralnego, ponieważ faktyczna władza zwyczajowo spoczywała w rękach regionalnych i lokalnych liderów. Wcześniejsze rządy centralne Afganistanu zazwyczaj były słabe i skorumpowane, a niektóre z nich społeczeństwo postrzegało za wrogie (Lawless, Constantineau, 2017, s. 65).

Powołany w 2002 roku przy wsparciu społeczności międzynarodowej gabinet pod przewodnictwem prezydenta Hamida Karzaja podtrzymał ten niechlubny obraz afgańskiego rządu. Nawet na tle sąsiednich państw wyróżniał się on głębokim skorumpowaniem i niekompetencją. Niektórzy obserwatorzy zaczęli nawet nazywać afgański system „kleptokracją" (,kleptocracy”) i „drapieżniczym reżimem” (,predator regime”) (Krause, Mallory, 2014, s. 3). Wbrew zapowiedziom idea „dobrego zarządzania” (,good governance") nie została zaimplementowana do systemu politycznego Afganistanu. W praktyce przez państwo przetoczyła się fala toksycznej korupcji. Rząd centralny okazał się być bezsilny, destrukcyjny i niereprezentatywny na poszczególnych poziomach struktury państwowej. Nie był w stanie zbudować silnych instytucji państwowych, wprowadzić porządku prawnego i zabezpieczyć fundamentalnych potrzeb społecznych, takich jak bezpieczeństwo, praca, czy dostęp do podstawowych mediów. $\mathrm{Z}$ tych powodów znacząco przyczynił się do pogłębienia niepokojów społecznych i wzrostu przemocy antypaństwowej (Keane, 2016, s. 7).

Przez ponad dekadę za utrzymanie bezpieczeństwa w Afganistanie odpowiedzialne były stacjonujące w nim zagraniczne kontyngenty wojskowe. Za ich pośrednictwem 
społeczność międzynarodowa formowała, szkoliła i doposażała afgańskie siły bezpieczeństwa. Mimo tych wysiłków zarówno Afgańska Armia Państwowa (Afghan National Army - ANA), jak i przede wszystkim Afgańska Policja Państwowa (Afghan National Police - ANP) z podległymi jej filarami pomocniczymi, w tym Afgańską Policją Lokalną (Afghan Local Police - ALP), zmagają się z szeregiem poważnych problemów, w tym z głęboką korupcją, słabym wyszkoleniem i wyposażeniem, nieefektywnym zarządzaniem i dowodzeniem oraz nadużywaniem przemocy wobec obywateli (Perito, 2012, s. 3). Szczególny niepokój budzą infiltracja ANDSF przez talibów i stwierdzone liczne przypadki współpracy żołnierzy i funkcjonariuszy z rebeliantami (Kulesa, Górka-Winter, 2012, s. 218). W regularnych strukturach ANDSF występują jednostki, które pozytywnie wyróżniają się na tle pozostałych. Zasadniczo jednak Afgańczycy nie mogą czuć się bezpiecznie i ufać rządowym siłom bezpieczeństwa. Ponadto setki tysięcy mieszkańców kraju, głównie terenów wiejskich, zmuszone są do współpracy z talibami i innymi nielegalnymi ugrupowaniami zbrojnymi, ponieważ nie mogą liczyć na ochronę ze strony państwa i jego instytucji. ANDSF nie są bowiem w stanie skutecznie realizować powierzonego im zadania utrzymania bezpieczeństwa państwa i jego obywateli (Whitlock, 2019; Dereń, 2015, s. 67).

Rozwój infrastruktury państwowej i inicjowanie aktywności gospodarczej w Afganistanie również było przede wszystkim zasługą społeczności międzynarodowej, a nie rządu centralnego. Wykorzystywano do tych celów między innymi Prowincjonalne Zespoły Odbudowy (Provincial Reconstruction Team - PRT). Ich międzynarodowy personel cywilno-wojskowy nadzorował inwestycje realizowane w całym kraju na wszystkich etapach realizacji. Wielomiliardowe środki pomocowe od społeczności międzynarodowej były wyjątkowo nieefektywnie dystrybuowane przez poszczególne poziomy afgańskiej administracji. Powodem tego była organiczna korupcja, niekompetencja, nepotyzm oraz arogancja pracowników aparatu państwowego. Według ostrożnych szacunków $40 \%$ środków pomocowych przekazywanych Afganistanowi zostało sprzeniewierzonych (Pawłuszko, 2012, s. 34). Powołane krajowe i międzynarodowe instytucje antykorupcyjne nie wywiązywały się z powierzonych im zadań. Jednym z powodów było utrudnianie im działania przez władze państwowe wysokiego szczebla (Schroeder, 2014, s. 51). W okresie funkcjonowania rządu Hamida Karzaja Jean-Charles Jauffret napisał, że ze wsparcia finansowego dla Afganistanu głównie korzystają ,,skorumpowani wysocy urzędnicy państwowi, gubernatorzy prowincji, którzy przechwytują pieniądze przeznaczone na pensje dla nauczycieli, dyrektorzy afgańskich organizacji pozarządowych i niektórzy oszukańczy zachodni i afgańscy przedsiębiorcy, którzy stają się podwykonawcami w projektach odbudowy kraju. Jednak największymi beneficjentami tych pojawiających się nagle niewyobrażalnych fortun są watażkowie, którzy weszli w szeregi administracji Karzaja" (Jauffret, 2014, s. 63).

Obietnice, nadzieje i oczekiwania znacznej poprawy jakości życia Afgańczyków w efekcie przyniosły rozczarowanie i zawód (Schroeder, 2014, s. 21). Przede wszystkim dotyczy to mieszkańców obszarów wiejskich, którzy w najmniejszym stopniu stali się beneficjentami zewnętrznej pomocy. Poczucie oszukania systematycznie prowadziło do odwracania się milionów Afgańczyków od rządu centralnego. Wielu z nich sytuacja ekonomiczna zmuszała do współpracy z talibami i innymi ugrupowaniami zbrojnej opozycji. Ostrzał baz wojsk koalicyjnych często następował z terenu afgańskich wsi, a czasem 
przeprowadzali go sami rolnicy, ponieważ mogli otrzymać za to relatywnie wysokie wynagrodzenie.

W pierwszych latach funkcjonowania demokratycznego rządu zaniedbywane były zamieszkałe przez Pasztunów południowo-wschodnie i południowo-zachodnie prowincje Afganistanu. W ostatnich latach stały się one jednak głównym konsumentem zewnętrznej pomocy. Wynika to z faktu, że w tych rejonach sytuacja jest najbardziej niestabilna. Większość środków pomocowych nie jest jednak przeznaczana na tworzenie podstaw samopodtrzymującego się rozwoju, a trafia na cele wojskowe (Cordesman, Hess, 2014, s. 122).

W obliczu rozkładu struktur administracji państwowej watażkowie i rebelianci mogą swobodnie administrować na kontrolowanych przez siebie obszarach, uzurpując sobie funkcje rządowe (Jones, 2010, s. 155). Z powodu skorumpowania lub zastraszenia władz regionalnych część środków pomocowych trafia bezpośrednio do nich. Ponadto korzystają oni ze skomplikowanej i niejasnej sieci powiązań i zależności między poszczególnymi decydentami.

\section{Konflikty wewnętrzne}

W Afganistanie istnieją podziały o charakterze religijnym (sunnici i szyici), narodowościowym (Pasztuni, Tadżycy, Chazarzy, Uzbecy, Turkmeni i in.) i plemienno-klanowym. Między poszczególnymi grupami występują poważne różnice w postrzeganiu świata, wiary, przyszłości, rozwoju oraz systemu politycznego, społecznego i ekonomicznego (Gryz, 2007, s. 22). Brak wśród Afgańczyków silnego jednoczącego pierwiastka powoduje, że dają o sobie znać zakorzenione w kulturze czynniki konfliktogenne, takie jak etnonacjonalizm, trybalizm, czy fundamentalizm religijny (Olchowski, 2010, s. 109). Między poszczególnymi grupami istnieją liczne nierozwiązane do dziś zaszłości historyczne oraz konflikty o różnym podłożu. Uniemożliwiają one tworzenie polityki historycznej, która byłaby do zaakceptowania przez wszystkie zainteresowane podmioty i stanowiła punkt wyjściowy do pojednania i zespolenia narodowego. W poszczególnych regionach państwa rywalizują ze sobą watażkowie dysponujący prywatnymi armiami i cieszący się poparciem różnych grup społecznych (Harshé, 2016, s. 20).

$\mathrm{Z}$ powodu wieloletnich walk między wrogimi ugrupowaniami struktury państwa zostały rozbite, a jego gospodarka prawie doszczętnie zniszczona (Harshé, 2016, s. 30). Po wojnie powstańczej przeciwko komunistycznemu reżimowi wspieranemu przez Sowietów w latach 80 . XX wieku, w latach 90 . XX wieku wystąpiły intensywne walki między rządem mudżahedinów i jego wrogami. Te waśnie o podłożu etnicznym i plemiennym odbywały się ogromnym kosztem ludności cywilnej (Maley, 2002, s. 194). Konsekwencją wojny domowej było pojawienie się ruchu talibów, który ze wsparciem Pakistanu miał położyć kres rozpętanej przez afgańskich watażków anarchii. Stanowiący mozaikę narodowościową Sojusz Północny stawiał zbrojny opór reżimowi zdominowanemu przez radykalnych Pasztunów. W 2001 roku otrzymał on wsparcie międzynarodowej koalicji wojskowej pod amerykańskim przywództwem, co pozwoliło na jego obalenie i radykalne zmniejszenie wpływów w Afganistanie pasztuńskiej większości. 
Podczas konferencji w Bonn z końca 2001 roku watażkowie z Sojuszu Północnego zabiegali o stanowiska w konstruowanym Tymczasowym Rządzie Afganistanu. Urzędy we władzach centralnych i regionalnych były im przekazywane w zamian za zobowiązanie dalszej walki przeciwko Al-Kaidzie i talibom. Przykładowo wojskowy przywódca Sojuszu Północnego Mohammed Fahim został ministrem obrony, lider afgańskich Uzbeków Raszid Dostum zastępcą ministra obrony i szefem sztabu generalnego, a wielkorządca Heratu Ismael Chan, choć niechętnie, ministrem energii (Jureńczyk, 2016b, s. 148). Z jednej strony prywatne armie watażków miały być zakazane, a $z$ drugiej niektóre $\mathrm{z}$ nich otrzymywały wydatne wsparcie Amerykanów, w postaci zapasów, w tym amunicji, aby prowadziły dalszą walkę (Keane, 2016, s. 65-66, 107-108). Stworzenie scentralizowanego systemu politycznego, nadanie wysokich urzędów części wewnętrznych liderów i marginalizacja wielu innych oraz alienacja stanowiących większość społeczeństwa Pasztunów były jednymi z kluczowych czynników prowadzących do pogłębiania się niestabilności w państwie (Qassem, 2016, s. 125).

Potężni watażkowie nie traktowali jak równego sobie wybranego na prezydenta Hamida Karzaja. Co za tym idzie ich lojalność wobec rządu, do którego wchodzili, była ograniczona. Również watażkowie mianowani na wysokie urzędy w terenie, w tym gubernatorów prowincji i dystryktów, rzadko byli skorzy do współpracy na rzecz wzmocnienia $\mathrm{w}$ regionie aparatu państwowego. $\mathrm{Z}$ tego względu władze terenowe nie mogły cieszyć się zaufaniem rządu centralnego i stanowić dla niego odpowiedniego partnera do współpracy (Rietjens, 2012, s. 65-66). Watażkowie niechętnie tworzyli reprezentacyjne szury, uwzględniające głos każdej z zamieszkujących obszar grup etnicznych, czy plemiennych. Wpływowe osobistości najczęściej działały przeciwko sobie, co rodziło w regionalnych i lokalnych władzach klimat braku zaufania. W pierwszych latach XXI wieku watażkowie i dowodzone przez nich lokalne milicje w wielu prowincjach stanowiły znacznie większe zagrożenie dla ISAF i ANDSF niż talibowie. Siły koalicyjne wielokrotnie musiały interweniować w starciach zbrojnych między oddziałami poszczególnych watażków. Musiały również chronić urzędników państwowych i cywilów przed atakami nielegalnych milicji oraz zapobiegać negatywnym konsekwencjom ich zaangażowania w działalność przestępczą (Levi-Sanchez, 2017, s. 93).

Szereg podziałów istnieje również między działającymi na terenie Afganistanu ugrupowaniami rebelianckimi i terrorystycznymi. Mają one różne motywy działania, cele, metody prowadzenia walki i stosunek do ludności cywilnej, stąd też w zróżnicowany sposób postrzegana jest ich działalność przez Afgańczyków. Organizacje te różnymi metodami oddziałują i wpływają na społeczeństwo, często przeciwstawiając sobie i konfliktując poszczególne grupy religijne, etniczne i plemienne.

\section{Narkobiznes}

W 2017 roku areał uprawy maku w Afganistanie osiągnął szczytowy poziom 328 tys. hektarów. Był to najwyższy wzrost w historii Afganistanu, ponieważ w porównaniu z 2016 rokiem powierzchnia ta zwiększyła się o 127 tys. hektarów (UNODC, 2018, s. 2). Poziom ten znacząco przewyższył poprzednie szczyty, tj. 193 tys. hektarów w 2007 roku i 224 hektary w 2014 roku (UNODC, 2014, s. 6). Między 2016 a 2017 rokiem jeszcze 
większy wzrost nastąpił w potencjalnej produkcji opium, ponieważ uległa ona prawie podwojeniu z 4,8 tys. do 9 tys. ton. Wynikało to zarówno ze znacznego zwiększenia areału upraw, jak również dobrych zbiorów z hektara. Szacunkowo 57\% produkcji przypadło na południową części kraju, $16 \%$ na północną, 13\% na zachodnią i $9 \%$ na wschodnią (UNODC, 2018, s. 2).

Duży wzrost areału upraw maku wynika z kilku zasadniczych czynników. Po pierwsze, po zakończeniu misji ISAF zmniejszają się wpływy władzy państwowej w poszczególnych regionach kraju i co za tym idzie możliwości ich kontroli. Po drugie, obecna strategia władz Afganistanu zakłada intensyfikację walki z rebeliantami na obszarach zurbanizowanych, co odbywa się kosztem prowincji. Niestabilność polityczna i konflikty na poszczególnych poziomach władzy dodatkowo ograniczają wpływy aparatu państwowego na afgańskiej wsi. Próżnię tę wypełniają zarówno rebelianci i watażkowie, jak i organizacje przestępcze. Po trzecie, istotny wpływ mają czynniki ekonomiczne. W ostatnich latach zmniejszyło się zainteresowanie społeczności międzynarodowej Afganistanem. Przekłada się to na zmniejszenie inwestycji i znaczące spowolnienie wzrostu gospodarczego, a co za tym idzie wzrost poziomu bezrobocia i biedy. Rzesze rolników uzyskujących niewielkie przychody z produkcji żywności i niemających możliwości zatrudnienia w innych sektorach gospodarki decydują się przejść na opłacalną uprawę maku.

W 2017 roku przemysł narkotykowy w Afganistanie szacunkowo był wart między 4,1 a 6,6 mld dol., co w porównaniu z Produktem Krajowym Brutto (PKB) stanowiło aż między 20 a $32 \%$. Był to poziom niewiele mniejszy od udziału całego sektora rolnego Afganistanu w PKB. W 2017 roku sama uprawa i zbieranie maku miały dać ekwiwalent zatrudnienia 354 tys. pełnych etatów. Specyfika narkobiznesu sugeruje, że dużo więcej osób osiąga zyski z przetwarzania i handlu opiatami (UNODC, 2018, s. 5, 7). Szacunkowo z działalności narkotykowej w Afganistanie może uzyskiwać dochody nawet do 3 milionów osób, a znacznie więcej znajdować się na utrzymaniu za środki pozyskiwane $\mathrm{z}$ tego procederu. Władze Afganistanu nie są chętne do zwalczania upraw, ponieważ nie byłyby w stanie zapewnić rolnikom alternatywnego zatrudnienia. Mogłoby to spowodować, że wielu z nich przyłączyłoby się do rebeliantów.

W ostatnich latach szacunkowo 10\% przychodów biznesu narkotykowego w Afganistanie trafiać miało do rebeliantów, a ok. 70\% do siatki przestępczej, dystrybutorów i mafii transportowej. Główna część tych zysków trafiała do stojących na ich czele baronów narkotykowych i watażków (Cordesman, Hess, 2014, s. 121; Harshé, 2016, s. 27). Znamiennym jest, że niektórzy z nich pełnią wysokie funkcje w administracji państwowej i służbach bezpieczeństwa. Ponieważ zyski z narkobiznesu są ogromne, bossom zależy na destabilizacji państwa, aby ograniczyć wpływy rządu centralnego. Gdy ten próbuje ingerować w ich interesy, wykorzystują oni swoje nielegalne milicje do ich obrony. Najpoważniejszy problem stanowi wykorzystywanie zysków z narkobiznesu do finansowania rebelii prowadzonej przez talibów i inne ugrupowania zbrojnej opozycji. Wpływy dla rebeliantów pochodzą głównie z podatków od upraw. Badania przeprowadzone w 2017 roku w stanowiącej centrum przemysłu narkotykowego prowincji Helmand pokazały, że $36 \%$ podatków z pozyskiwania maku trafiało do lokalnych watażków i baronów narkotykowych, 35\% do talibów, 18\% do innych grup rebelianckich i antyrządowych, a 12\% do innych podmiotów (UNODC, 2018, s. 9). 
W Afganistanie powołano szereg instytucji przeznaczonych do walki z procederem narkotykowym, w tym Afgańską Policję Antynarkotykową (Counter Narcotics Police of Afghanistan - CNPA) (Jureńczyk, 2016a, s. 160). Co roku skazywanych za działalność narkotykową jest kilkaset osób, w tym kilkudziesięciu urzędników państwowych. Działania te są jednak utrudnione ze względu na zaangażowanie w narkobiznes wielu polityków, oficerów ANDSF, a nawet pracowników wymiaru sprawiedliwości. W okresie prezydentury Hamida Karzaja proceder ten dotyczył nawet członków jego rządu i osób z najbliższego otoczenia. W stan oskarżenia pod tym zarzutem postawieni zostali między innymi minister obrony i późniejszy wiceprezydent Afganistanu - Mohammad Fahim (Sieff, Salahuddin, 2014) oraz przyrodni brat prezydenta - Ahmed Wali Karzaj (Gruszczak, 2011, s. 28). Jak więc widać proceder ten jest istotnym czynnikiem destabilizującym państwo i osłabiającym jego struktury oraz przyczynia się do wzrostu przemocy zbrojnej w Afganistanie.

Narkobiznes oczywiście nie jest jedynym wewnętrznym źródłem pozyskiwania środków finansowych na prowadzenie działalności rebelianckiej i terrorystycznej. Wśród nich znajdują się także między innymi nielegalne podatki różnego typu pobierane na kontrolowanych obszarach, haracze i wymuszenia, wpływy z nielegalnego obrotu towarami, w tym bronią, zbiórki na rzekome cele charytatywne, czy pranie brudnych pieniędzy. Wraz z inwestycjami zagranicznych przedsiębiorstw w afgański przemysł wydobywczy nasila się również rywalizacja nielegalnych ugrupowań zbrojnych o udział we wpływach z eksploatacji surowców naturalnych.

\section{Zakończenie}

We współczesnym Afganistanie występują złożone i wieloaspektowe przyczyny akceptacji przemocy niepaństwowych ugrupowań zbrojnych. Wynikają one z czynników historycznych, politycznych, kulturowych, społecznych i ekonomicznych, a w ich tle znajdują się przesłanki natury psychologicznej. Dla każdej z tych przyczyn można wskazać wspólne elementy. Są nimi odmienne postrzeganie tych samych zjawisk, rozbieżny światopogląd i system wartości oraz kolizyjne lub sprzeczne cele i interesy. Ponadto są one ze sobą sprzężone i wzajemnie się warunkują. Przykładowo bezpardonowa ingerencja mocarstw podsyca konflikty kulturowe, a niezdolność zarządzania państwem przekłada się na pogłębienie wewnętrznych antagonizmów i wzrost przestępczości. W ramach postkolonialnego nurtu podejścia do bezpieczeństwa, szczególne znaczenie odgrywają historyczne i współczesne stosunki z mocarstwami. W historii Afganistanu przemoc zbrojna była zjawiskiem często występującym. Również współcześnie wojna w Afganistanie trwa w zmiennym kształcie od prawie czterech dekad. Najpierw była to interwencja Związku Radzieckiego, potem wojna domowa między ugrupowaniami mudżahedinów, następnie kampania wojenna talibów, aż w końcu interwencja zbrojna międzynarodowej koalicji pod amerykańskim przywództwem i wojna domowa przeciwko rebeliantom i terrorystom.

Obecnie nie widać perspektyw na zakończenie fali przemocy w Afganistanie. Talibowie wykazują zaskakującą zdolność przetrwania i mają atuty, które pozwalają im prowadzić działania zbrojne jeszcze przez długi czas. Mają znaczne arsenały broni z poprzednich 
wojen, środki finansowe z handlu opium, duże możliwości rekrutacyjne na pasztuńskiej prowincji, schronienie w Pakistanie (O’Connell, 2017), sprawdzoną taktykę działań zbrojnych w trudnym terenie afgańskim i strategiczną cierpliwość. Również Amerykanie, zważywszy na swoją potęgę militarną i ekonomiczną, są w stanie wspierać afgański rząd i jego siły bezpieczeństwa w długim okresie czasu. Przewaga technologiczna powoduje, że mogą to czynić przy niewielkim zaangażowaniu osobowym. Żadna ze stron nie dysponuje jednak atutami, które umożliwiłyby jej ostateczne zwycięstwo w tej wojnie. Wygrana wymaga bowiem nie tylko przewagi militarnej, ale także poparcia społecznego. $Z$ tego względu strony rywalizują ze sobą także w płaszczyźnie propagandowej.

W Afganistanie istnieje również szereg innych niż organizacje rebelianckie podmiotów, które stosują przemoc zbrojną. Wśród nich należy przede wszystkim wskazać skonfliktowanych ze sobą watażków, którzy reprezentują poszczególne grupy etniczne, plemienne, klanowe i religijne. Sytuację w państwie destabilizują również przestępcy, którzy sięgają po siłę zbrojną w celu ochrony i rozszerzania swoich nielegalnych interesów oraz organizacje terrorystyczne. Polityka słabego, nieudolnego i skorumpowanego rządu Afganistanu nie jest w stanie zahamować tej przemocy. Wręcz przeciwnie, jego postawa istotnie przyczynia się do wzrostu siły i poparcia społecznego dla destabilizujących Afganistan niepaństwowych ugrupowań zbrojnych. W związku z powyższym, perspektywa dla Afganistanu jest negatywna i przemoc zbrojna w tym państwie może występować jeszcze przez wiele kolejnych lat.

Zakończenie udzielania wsparcia Afganistanowi przez społeczność międzynarodową doprowadziłoby do jeszcze poważniejszej destabilizacji kraju i w konsekwencji odzyskania władzy przez talibów. Afganistan potrzebuje pomocy militarnej, głównie w postaci wzmożonych działań na rzecz profesjonalizacji ANSDF, a także gospodarczej, humanitarnej i eksperckiej. Konieczna jest intensyfikacja wysiłków na rzecz uzdrowienia aparatu państwowego Afganistanu i promocja pojednania narodowego. Mimo, że jak dotąd działania te przynosiły ograniczone rezultaty, to obecnie nie widać dla nich rozsądnej alternatywy. Dla przyszłości Afganistanu kluczowa jest postawa społeczeństwa. Jeśli jego przyzwolenie na przemoc niepaństwowych ugrupowań zbrojnych wzrośnie, to sytuacja bezpieczeństwa w Afganistanie będzie ulegać dalszemu pogarszaniu.

\section{Bibliografia}

Ayoob M. (1980), The Roots of Conflict, w: Conflict and Intervention in the Third World, red. M. Ayoob, Australian National University Press, Canberra.

Briscoe I. (2013), Non-conventional armed violence and non-state actors: challenges for mediation and humanitarian action, May, https:/www.clingendael.org/sites/default/files/pdfs/Non-conventional $\% 20$ armed $\% 20$ violence $\% 20$ and $\% 20$ non-state $\% 20$ actors, $\% 20$ challenges $\% 20$ for $\% 20$ mediation\%20and\%20humanitarian\%20action.pdf, 10.01.2020.

Cordesman A., Hess A. (2014), Prospects for transition In Afghanistan, w: Afghanistan, Pakistan and Strategic Change. Adjusting Western regional policy, red. J. Krause, Ch. K. Mallory IV, Routledge, London-New York.

Coupland R. M. (2001), Armed Violence, „M\&GS”, no. 7.

Crawford N. C. (2016), Update on the Human Costs of War for Afghanistan and Pakistan, 2001 to mid2016, August, http://watson.brown.edu/costsofwar/files/cow/imce/papers/2016/War\%20in\%20 Afghanistan\%20and\%20Pakistan\%20UPDATE_FINAL_corrected\%20date.pdf, 22.06.2018. 
Czaputowicz J. (2012), Bezpieczeństwo międzynarodowe. Współczesne koncepcje, Wydawnictwo Naukowe PWN, Warszawa.

Dereń J. (2015), Afganistan: ofiara geopolitycznych gier czy wojownik etnicznych wojen, w: Afganistan 2014 - rok zwycięstwa czy rok porażki? Doświadczenia dla przyszłości, red. A. Drzewicki, G. Rdzanek, BEL Studio, Warszawa.

Englehart N. A. (2016), Non-state Armed Groups as a Threat to Global Security: What Threat, Whose Security?, „Journal of Global Security Studies”, no. 1(2).

Geib R. (2009), Armed violence in fragile states, „International Review of the Red Cross”, vol. 91, no. 873 .

Gorodnichenko Y., Roland G. (2012), Understanding the Individualism-Collectivism Cleavage and its Effects: Lessons from Cultural Psychology, https://eml.berkeley.edu/ groland/pubs/IEA\%20 papervf.pdf, 15.01.2020.

Gruszczak A. (2011), Is NATO still needed? An unorthodox perspective on the North Atlantic Treaty Organization on the example of the Afghan conflict, ,The Yearbook of International Security”.

Gryz J. (2007), Ewolucja znaczenia sity militarnej w polityce międzynarodowej, w: Afganistan: militarny i pozamilitarny wymiar stabilizacji. Materialy z konferencji naukowej zorganizowanej 12 kwietnia 2007 r., red. D. Strasburger i in., Akademia Obrony Narodowej, Warszawa.

Gwiazda A. (2007), Stabnace państwo, „Świat Idei i Polityki”, t. 7.

Harshé R. (2016), Situating Afghanistan in a globalizing world, w: Afghanistan Post-2014. Power configurations and evolving trajectories, red. R. Harshé, D. Tripathi, Routledge, New DelhiLondon-New York.

Hoehn A. R., Harting S. (2010), Risking NATO: testing the limits of the alliance in Afghanistan, RAND Corporation, Santa Monica.

Institute for Economics \& Peace (2019), Global Terrorism Index 2019. Measuring the Impact of Terrorism, http://visionofhumanity.org/app/uploads/2019/11/GTI-2019web.pdf, 15.01.2020.

Jahangir A., Javaid U. (2018), Afghanistan Imbroglio: The Unintended Consequences of Foreign Interventions, „South Asian Studies”, vol. 33, no. 2.

Jauffret J. Ch. (2014), Afganistan 2001-2013. Kronika przepowiedzianego braku zwycięstwa, thum. E. Cylwik, J. Sheybal, Wydawnictwo Dialog, Warszawa.

Jones S. G. (2010), In the Graveyard of Empires. America's War in Afghanistan, W. W. Norton \& Company, New York-London.

Jureńczyk Ł. (2007), Fundamentalizm muzutmański afgańskich talibów i ich stosunek do innych religii, „Polityka i Społeczeństwo”, nr 4.

Jureńczyk Ł. (2013), Wojna z talibami i Al-Kaida. Afganistan w latach 1994-2012, Wydawnictwo Grado, Toruń.

Jureńczyk Ł. (2016a), Narkobiznes w Afganistanie, „Kwartalnik Bellona”, nr 1.

Jureńczyk Ł. (2016b), Polska misja w Afganistanie. Wojsko Polskie w operacji reagowania kryzysowego NATO, Wydawnictwo Uniwersytetu Kazimierza Wielkiego, Bydgoszcz.

Kamiński T. (2008), Afganistan. Parła nist, Oficyna Wydawnicza Branta, Bydgoszcz-Warszawa.

Keane C. (2016), US-Nation Building in Afghanistan, Routledge, London-New York.

Koplan J. P., Rosenberg M., Krug E. (1998), Violence prevention: A public health policy, Centers for Disease Control and Prevention, Atlanta.

Krause J., Mallory Ch. K. IV (2014), Adjusting Western strategy towards Afghanistan and Pakistan, w: Afghanistan, Pakistan and Strategic Change. Adjusting Western regional policy, red. J. Krause, Ch. K. Mallory IV, Routledge, London-New York.

Kulesa Ł., Górka-Winter B. (2012), From followers to leaders as 'coalition servants': the Polish engagement in Afghanistan, w: Statebuilding in Afghanistan. Multinational contributors to reconstruction, red. N. Hynek, P. Marton, Routledge, London-New York. 
Langenfeld P. (2011), Afganistan. Dotknątem wojny, Wydawnictwo ENDER, Ustron.

Levi-Sanchez S. (2017), The Afghan-Central Asia Borderland. The state and local leaders, Routledge, London-New York.

Lawless G. J., Constantineau P., Dizboni A. (2017), A Hermeneutic Analysis of Military Operations in Afghanistan, Palgrave Macmillan, New York.

Maley W. (2002), The Afghanistan Wars, Palgrave Macmillan, New York.

McQuinn B., Oliva F. (2018), Preliminary scoping report analyzing and engaging non-state armed groups in the field, United Nations System Staff College, Torino.

Modrzejewska-Leśniewska J. (2010), Afganistan, Wydawnictwo Trio: Warszawa.

Moïsi D. (2012), Geopolityka emocji, tłum. R. Włoch, Wydawnictwo Naukowe PWN, Warszawa.

O'Connell A. B. (2017), Why we aren 't 'winning' in Afghanistan, „The Washington Post”, 10 August, https://www.washingtonpost.com/opinions/america-is-relying-too-much-on-military-powerin-afghanistan/2017/08/10/102a565e-7d19-11e7-a669-b400c5c7e1cc_story.html?utm_term=. f7fecb9d7c68, 22.06.2018.

Ogdowski M. (2011), Z Afganistanu.pl. Alfabet polskiej misji, Wydawnictwo ENDER, Ustroń.

Olchowski J. (2010), Kultura i zjawiska dezintegracji i konfliktu, w: Międzynarodowe stosunki kulturalne, red. R. Zenderowski, K. Cebul, M. Krycki, Wydawnictwo Naukowe PWN, Warszawa.

Pawłuszko T. (2012), Afganistan w polityce Stanów Zjednoczonych, w: Stracona dekada? Polityka bezpieczeństwa Stanów Zjednoczonych wobec „, globalnych obszarów niestabilności” (Iraku, Iranu, KRL-D oraz Afganistanu) w latach 2001-2011, red. Ł. Smalec, Wydział Dziennikarstwa i Nauk Politycznych Uniwersytetu Warszawskiego, Warszawa.

Perito R. M. (2012), Afghanistan's Civil Order Police. United States Institute of Peace Special Report, Washington, May, http://www.usip.org/sites/default/files/SR307.pdf, 22.06.2018.

Qassem A. S. (2016), Afghanistan's Political Stability. A Dream Unrealised, Routledge, London-New York.

Rączkiewicz M. (2011), Polityka Stanów Zjednoczonych Ameryki w okresie prezydentury G. W. Busha w ujęciu regionalnym, Wydawnictwo Adam Marszałek, Toruń.

Rietjens S. (2012), Between expectations and reality: the Dutch engagement in Uruzgan, w: Statebuilding in Afghanistan. Multinational contributors to reconstruction, red. N. Hynek, P. Marton, Routledge, London-New York.

Schroeder R. (2014), Not too little, but too late: ISAF's strategic restart of 2010 in light of the coalition's previous mistakes, w: Afghanistan, Pakistan and Strategic Change. Adjusting Western regional policy, red. J. Krause, Ch. K. Mallory IV, Routledge, London-New York.

Sellin J. Th. (1938), Culture Conflict and Crime, „American Journal of Sociology”, vol. 44, no. 1, http://www.jstor.org/stable/2768125?seq=1\#page_scan_tab_contents, 22.06.2018.

Sepp K. I. (2006), Best Practices in Counterinsurgency, „Military Review”, October, Special Edition.

Sieff K., Salahuddin S. (2014), Mohammad Quasim Fahim: The first vice-president of Afghanistan, whose career was dogged by allegations of atrocities and corruption, „Independent”, 11 March, http://www.independent.co.uk/news/obituaries/mohammad-qasim-fahim-the-firstvicepresident-of-afghanistan-whose-career-was-dogged-by-allegations-of-atrocities-and-corruption-9182663.html, 22.06.2018.

Sierakowska-Dyndo J. (2007), Granice wyobraźni politycznej Afgańczyków. Normatywno-aksjologiczne aspekty tradycji afgańskiej, Wydawnictwo Uniwersytetu Warszawskiego, Warszawa.

The Fund for Peace (2019), Fragile States Index. Annual Report 2019, https://fundforpeace.org/wpcontent/uploads/2019/04/9511904-fragilestatesindex.pdf, 15.01.2020.

UNAMA (2018), Afghanistan. Protecting of Civilians in Armed Conflict. Annual Report 2017, 15 February, https://unama.unmissions.org/afghanistan-10000-civilian-casualties-2017-un-report-suicide-attacks-and-ieds-caused-high-number, 22.06.2018. 
UNODC (2014), Afghanistan Opium Survey 2014, November, https://www.unodc.org/documents/ crop-monitoring/Afghanistan/Afghan-opium-survey-2014.pdf, 22.06.2018.

UNODC (2018), Afghanistan Opium Survey 2017, May, https://www.unodc.org/documents/crop-monitoring/Opium-survey-peace-security-web.pdf, 22.06.2018.

Whitlock C. (2019), In documents, US military trainers describe Afghan security forces as incompetent, unmotivated and rife with deserters, ,Stars and Stripes”, 9 December, https://www.stripes.com/ in-documents-us-military-trainers-describe-afghan-security-forces-as-incompetent-unmotivated-and-rife-with-deserters-1.610484, 15.01.2020.

Williams M. J. (2011), The Good War. NATO and the Liberal Conscience in Afghanistan, Palgrave Macmillan, New York.

Zając J. (2010), Państwa arabskie wobec europejskiej koncepcji demokracji i praw człowieka, w: Kulturowe uwarunkowania rozwoju w Azji i Afryce, red. K. Górak-Sosnowska, J. Jurewicz, Wydawnictwo Ibidem, Łódź.

\title{
The main reasons for the acceptance of violence by non-state armed groups in modern Afghanistan
}

\begin{abstract}
Summary
The aim of the article is to analyze the main reasons for the acceptance of violence by non-state armed groups in modern Afghanistan. The research problem is included in the question, what are the main reasons for the acceptance of military activity of non-state actors by the part of Afghan society? These are mainly radical Islamist groups, warlords and their illegal militias, but also terrorist and criminal organizations. Among the main reasons the author indicates the interference of the great powers, the occupation and activities of coalition forces, cultural conflict and violation of cultural values, corruption and incompetence of the authorities, internal conflicts and narco-business. They are of historical, political, cultural, social and economic nature and have psychological premises in their background. In addition, they are complex and interrelated. They are united by common elements, such as a different perception of the same phenomena by the parties to the conflict, a divergent worldview and a system of values, and collisional or conflicting goals and interests. Within the postcolonial approach to security, historical and contemporary relations with the great powers are of particular importance. Armed violence consumes thousands of victims each year in Afghanistan. The causes of this violence, the nature of the conflict and the specificity of the fighting parties mean that in the near future we should not expect a reduction in the level of armed violence in Afghanistan. The international community can't turn its back on Afghanistan, because it would lead to an even more serious destabilization of the country and, in consequence, regaining power by the Taliban.
\end{abstract}

Key words: contemporary Afghanistan, non-state armed groups, military violence, Afghan government 